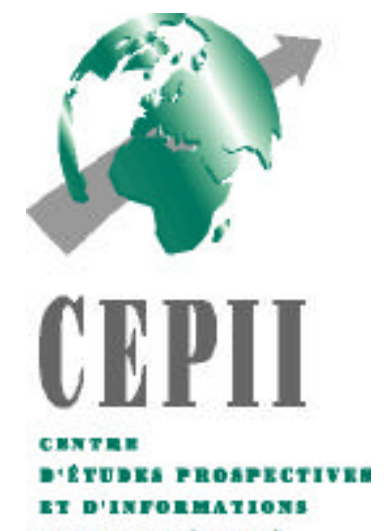

$2000-03$, janvier

What Drove Relative Wages in France? Structural Decomposition Analysis in a General Equilibrium Framework, 1970-1992

Sébastien J ean Olivier Bontout 

What Drove Relative Wages in France? Structural Decomposition Analysis in a General Equilibrium Framework, 1970-1992

Sébastien J ean Olivier Bontout

N² 2000 - 03, janvier 



\section{TABLE OF CONTENTS}

SUMMARY. 3

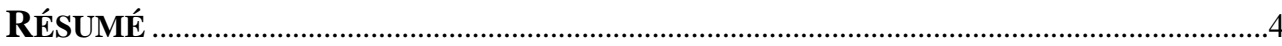

INTRODUCTION

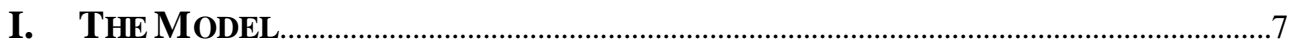

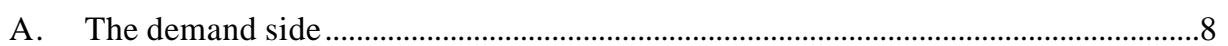

B. The supply side......................................................................................................

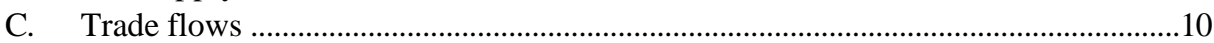

D. Production factor markets ..........................................................................................11

II. DECOMPOSITION ANALYSIS IN A GENERAL EQUILIBRIUM FRAMEWORK:

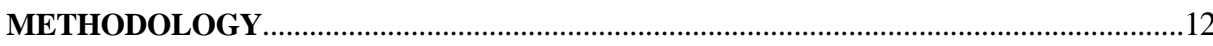

A. Structural model and state variables …………………………………………………....12

B. From state variables to decomposition analysis .....................................................12

C. Accounting for changes in international trade intensities ........................................13

D. Accounting for changes in the sector distribution of consumption .........................14

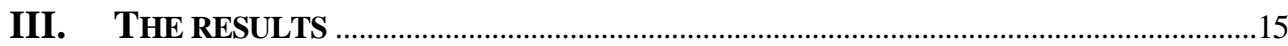
A. Stylised facts
. .15
B. Results of the decomposition analysis ....................................................................17
C. The link between trade and productivity ...................................................................18
D. Sensitivity to the substitutability between production factors ..................................20

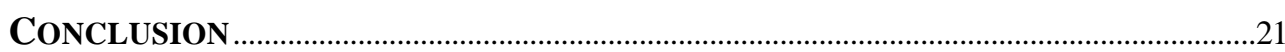

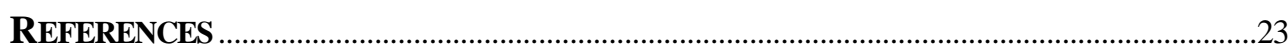

ANNEX 1: MODELLING IMPERFECT COMPETITION IN INDUSTRIAL SECTORS ........25

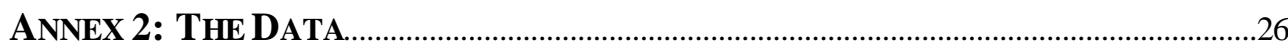

ANNEX 3: MODELING THE TRADE-INDUCED EFFECT ON PRODUCTIVITY..................27

LIST OF WORKING PAPERS RELEASED BY CEPII .............................................................29 
What Drove Relative Wages in France? Structural Decomposition Analysis in a General Equilibrium Framework, 1970-1992

\section{SUMMARY}

This paper confronts a CGE model to observed evolutions in France, between 1970 and 1992, through a structural decomposition analysis. The choice of the model and the assumption of constant elasticities over time enable the structural change of the economy between two equilibria to be summarised through a set of four types of state variables, reflecting the effect of technical change, changes in factor supplies, shifts in consumption patterns, and international trade. Simulations then allow the contribution of each of these shocks to be assessed. We find that technical change had a strong positive impact on the relative wage of skilled to unskilled workers, while the impact of changes in factor supplies is strongly negative. The effect of international trade is far less important. However, if we take into account a trade-induced effect on productivity, then we find that trade substantially increased wage inequalities.

JEL Classification: D58, F16.

Key-words: Decomposition analysis; General equilibrium model; Relative wages; France. 


\section{RÉSUMÉ}

Ce travail analyse les causes d'évolution structurelle des salaires réels concurrentiels des travailleurs qualifiés et non qualifiés en France, entre 1970 et 1992. L'analyse menée s'inscrit dans un cadre néo-classique, et repose sur une utilisation particulière d'un modèle d'équilibre général calculable. Le modèle n'est pas utilisé pour effectuer des simulations prospectives concernant l'effet d'un choc donné ; il sert à évaluer quelle a été la contribution des grandes catégories de chocs exogènes (progrès technique, accumulation de facteurs, modification des goûts des consommateurs, ouverture commerciale) dans les évolutions structurelles observées entre ces deux dates. Cette méthode présente l'avantage de fournir une évaluation cohérente des différents effets, à la fois en termes de méthodologie (un seul modèle structurel est utilisé) et en termes de résultats (la somme des contributions estimées est effectivement égale à la variation totale observée).

Le modèle utilisé distingue trois facteurs de production (travail qualifié, travail non qualifié et capital) et décompose l'économie française en neuf secteurs, en prenant en compte séparément pour chacun d'eux les flux de commerce extérieur avec les pays pauvres et avec les pays riches. Les secteurs industriels sont supposés bénéficier d'économie d'échelle, dans un contexte de concurrence monopolistique à la Cournot.

Le salaire réel (calculé ici comme la rémunération réelle totale, y compris les charges sociales employeurs et salariés) du travail non qualifié en France a augmenté plus rapidement, entre 1970 et 1992 , que celui du travail qualifié $:+51 \%$, contre $+33 \%$. Mais un chômage structurel s'est développé dans le même temps, passant d'un niveau négligeable à $7 \%$ environ, et ce type de chômage touche exclusivement les non-qualifiés. Le modèle n'étant pas destiné à décrire les imperfections du marché du travail, le problème est posé ici en termes de niveau concurrentiel de salaire des différentes catégories de travail; cela signifie qu'une simulation est effectuée, à partir de la base de donnée décrivant l'économie française en 1992, pour déterminer quel serait son état d'équilibre si les salaires étaient parfaitement flexibles, et donc si le chômage structurel était nul. Ce sont les rémunérations des facteurs dans cette dernière situation de plein emploi (les chômages frictionnel et conjoncturel ne sont pas pris en compte dans une analyse de ce type) que nous considérons comme concurrentielles. Cette correction amène à revoir à la baisse l'évolution du salaire du travail non qualifié, et à la hausse celle du salaire des qualifiés. Finalement, d'après nos estimations, le salaire réel concurrentiel aurait augmenté d'environ $40 \%$, pour les qualifiés comme pour les non-qualifiés.

Cette stagnation du niveau concurrentiel du salaire relatif qualifiés / non-qualifiés est le résultat d'effets contraires d'ampleur importante. Nos simulations indiquent ainsi que le progrès technique aurait eu un fort impact positif sur le salaire relatif des qualifiés, tandis que l'effet des variations des offres de facteurs de production est fortement négatif. L'évolution des goûts des consommateurs a une influence positive, mais d'ampleur nettement plus faible, sur le salaire relatif des qualifiés, du fait du déplacement de la demande vers le secteur des services, dont la main-d'oenvre est plus qualifiée que la 
What Drove Relative Wages in France? Structural Decomposition Analysis in a General Equilibrium Framework, 1970-1992

moyenne. Le commerce international a un impact positif sur la rémunération de chacun des trois facteurs, principalement en raison de la baisse du prix relatif des importations. Cet effet est plus favorable sur le travail qualifié, mais son salaire relatif par rapport au travail non qualifié est peu modifié. Ce n'est plus le cas dès que l'on suppose que le commerce international a un impact endogène sur la productivité et la qualification du travail au sein des secteurs : l'ouverture commerciale apparaît alors comme un facteur d'accroissement sensible du salaire relatif du travail qualifié par rapport au travail non qualifié. 


\title{
What DROVE RELATIVE WAGES IN FRANCE? STRUCTURAL Decomposition ANALYSIS in a GeNERAL EQUiLibrium FRAMEWORD, 1970-1992
}

\author{
Sébastien Jean and Olivier Bontout ${ }^{1}$
}

\section{INTRODUCTION}

Various causes are invoked to explain the recent evolutions of skilled to unskilled relative wage in industrialised countries. The most important ones are probably five: changes in factor supplies, modifications of consumption patterns, institutional changes, technical change and international trade. In spite of the abundant literature on the subject, it remains difficult to have a clear view of the role of these determinants.

Their impact is in most cases studied separately, using ad hoc methods (factor content of trade calculations, for example) or econometric analysis based on reduced forms. Informative as they are, these kinds of studies only tell part of the story. The residual, unexplained variations in relative wages are then often attributed to the causes not taken into account. Such an assessment does not account for the possible interactions between the various causes, and it does not check the consistency of the overall explanation.

Other studies adopt a radically different approach, based on general equilibrium modelling. Recent examples include Rowthorn (1995), Cortes and Jean (1996, 1998), Cardebat and Teï letche (1997), Lawrence and Evans (1997), Bontout and Jean (1998) and Francois and Nelson (1998). These works are useful in clarifying the prevailing mechanisms. It is difficult, however, to understand how well these models explain observed evolutions. They generally focus on part of the possible causes, and they either rely on stylised databases or adopt a prospective standpoint.

As emphasised by Abrego and Whalley (1999), the choice of a structural model has strong implications for the interpretation of given observations. They insist that "it is important to explicitly explore the properties of particular structural models in decompositions, rather than only appealing to them as theoretically consistent models for reduced form analyses".

In this paper, we confront a CGE model to observed evolutions in France, between 1970 and 1992, through a structural decomposition analysis.

\footnotetext{
${ }^{1}$ Sébastien Jean is economist at the CEPII. Olivier Bontout is economist at the DREES (French Ministry of Labour). The authors are grateful to Jean-Louis Guérin, Nanno Mulder, Laurence Nayman and Pierre Villa for helpful comments. They also benefited from comments of participants to the CEPR/CSLA Workshop International Trade and Wage Inequality: Theory and Measurement, Università Bocconi, Milan, 22/23 October 1999, where a preliminary version of this paper was presented. Usual disclaimers apply. Corresponding author : Sébastien Jean, CEPII, 9 rue Georges-Pitard, 75740 Paris Cedex 15, France; Tel: ++ 331536855 17; Fax: ++ 3315368 42 17; E-mail : s.jean@cepii.fr.
} 
We first choose the structural model, and assume constant the elasticities of substitution over time, both in the utility function and production function. Given these parameters (set on the basis of existing econometric studies), the structural equilibrium of the economy is determined by four categories of parameters and exogenous variables, which therefore form a set of state variables: share coefficients in the production function, reflecting the productivity for each factor within each sector; factor supplies, assumed to be exogenous; share coefficients in the utility function, reflecting consumers preferences; and, for each sector, the relative price of imports, as a proportion of domestic output price.

However, wage rigidities and institutional changes are not accounted for. We do not take into account frictional and cyclical unemployment, hence the assumption of full employment in 1970. From the 1992 database and given the observed structural unemployment at this date, we compute an "underlying full-employment equilibrium", assuming that relative wages adapt in order to remove this unemployment. The equilibrium obtained is considered as the benchmark for 1992. The study then analyses the causes of evolution of the French economy between these two full-employment equilibria, assuming that wages are perfectly flexible. This is most of all a way to avoid addressing the questions of changes in wage rigidities and institutional aspects of the labour market, for which CGE models are not really well-suited.

Structural change of the French economy between 1970 and 1992 can thus be summarised through the changes in these four categories of state variables. To analyse their role, we built a database for 1970 and for 1992. For the latter, we used the same physical units, for goods and factors, as for the former. The total change over the period can then be decomposed, in order to determine the contribution of each category of state variables.

This procedure makes it possible to estimate the contributions of technical change, factor supplies variations, shifts in the sectoral consumption pattern, and shift in trade intensities, in the variations of welfare and of each factor's real reward.

The model used is briefly presented in Section I. We then precise the methodology for the decomposition analysis (Section II). The results are presented in Section III, where we also study the importance of a possible endogenous effect of trade on productivity, and where we analyse how the results differ with a higher substitutability between production factors.

\section{THE MODEL}

The computable general equilibrium (CGE) model presented in this section has been conceived with the objective of providing a rough analysis of the structural change of the French economy. It is built on the basis of the model we used in Jean and Bontout (1998), which is in many respects similar to those developed by Gasiorek, Smith and Venables (1992) and Mercenier (1992) for the assessment of European economic integration, as well as to the one proposed by Cortes and Jean $(1996,1998)$ for dealing with the emergence of lowlabour-cost countries. This model uses an Armington hypothesis, but it also incorporates, for French industrial sectors only, horizontal product differentiation, monopolistic competition and increasing returns to scale. 
The model focuses on France (including its trade flows, separately with a Southern and a Northern $^{2}$ area). Nine sectors are distinguished, eight of which belong to agriculture and industry. Services are gathered in a single sector. We consider three production factors: unskilled labour, skilled labour and capital.

\section{A. The demand side}

Final consumption and intermediate consumption are modelled in the same way. For each of them, the demand function is supposed to be homothetic, and the representative consumer behaviour is modelled in three stages (see Figure 1). The first level describes the distribution of demand between industries. It is represented through a CES utility function, with an elasticity of substitution $\sigma_{l}$ equal to 0.5 . The share of an industry in total expenditure thus increases with its relative price.

\section{Figure 1: Structure of the utility function}

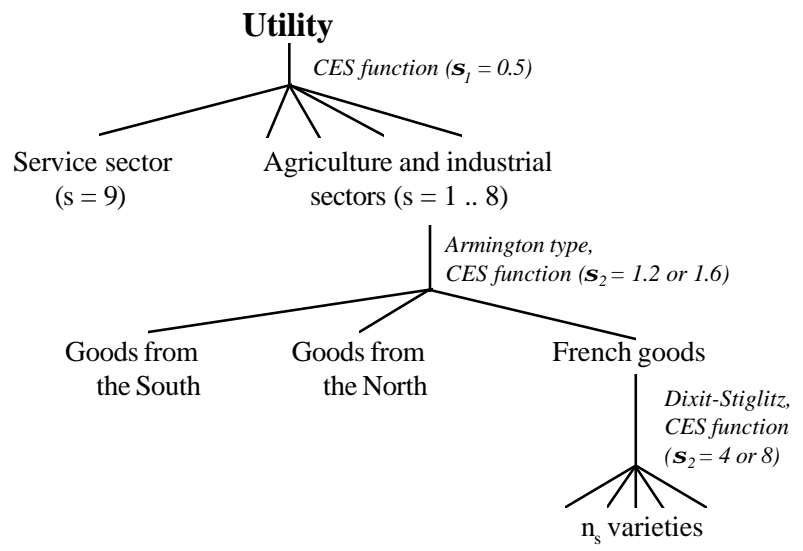

This is the only tier for the service sector, where goods are assumed to be homogenous and non-tradable. Within each other sector, in contrast, we use an Armington hypothesis: the choice between products from different geographical origins (France, North and South) is modelled through a CES function, with an elasticity of 1.2 for the high-differentiation sectors, and 1.6 for the low-differentiation ones (see Table 1). A third tier is modelled, for French products only, corresponding to a Dixit-Stiglitz formulation: the consumer chooses between horizontally-differentiated varieties of each good, with a constant elasticity of substitution (equal to 4 in high-differentiation sectors and 8 in low-differentiation ones).

\footnotetext{
${ }^{2}$ This Northern area includes the countries the GDP in PPP per capita of which was greater than $80 \%$ of the French one in 1980: USA, Canada, Switzerland, Japan, Australia, Norway, New-Zealand, and EU-15, except Spain, Greece, Portugal and Ireland. The Southern area corresponds to the rest of the World.
} 
What Drove Relative Wages in France? Structural Decomposition Analysis in a General Equilibrium Framework, 1970-1992

Table 1: Sectoral parameters (elasticity and fixed costs)

\begin{tabular}{|c|c|c|c|}
\hline & $\begin{array}{c}\text { Sigma2 (Armington } \\
\text { elasticity) }\end{array}$ & $\begin{array}{c}\text { Sigma3 (elasticity of } \\
\text { substitution between } \\
\text { French varieties) }\end{array}$ & $\begin{array}{c}\text { Fixed costs, as a } \\
\text { proportion of total cost } \\
\end{array}$ \\
\hline 1 Agriculture & 1,6 & 8 & 0,15 \\
\hline 2 Agro-food industry & 1,2 & 4 & 0,30 \\
\hline 3 Energy & 1,6 & 8 & 0,15 \\
\hline 4 Intermediate goods & 1,6 & 8 & 0,15 \\
\hline 5 Professional equipment goods & 1,2 & 4 & 0,30 \\
\hline 6 Households equipment goods & 1,6 & 8 & 0,15 \\
\hline 7 Transport materials & 1,2 & 4 & 0,30 \\
\hline 8 Current consumption goods & 1,6 & 8 & 0,15 \\
\hline
\end{tabular}

\section{B. The supply side}

The production function involves intermediate consumptions and the three types of production factors. It is a nesting of two functions (see Figure 2). Firstly, intermediate goods and value added are assumed to be perfectly complementary, as reflected by the use of a Leontief function. The service sector is assumed to exhibit constant returns to scale. For all other sectors, however, we take into account at this level the presence of fixed costs, inducing economies of scale. These fixed costs correspond to $15 \%$ of the initial output in low-differentiation sectors (where the elasticity of substitution between French varieties is 8, and the Armington elasticity is 1.6), and to $30 \%$ in high-differentiation ones (with elasticities in demand of 4 and 1.2), and this percentage is assumed to hold both in 1970 and in 1992.

\section{Figure 2: Structure of the production function}

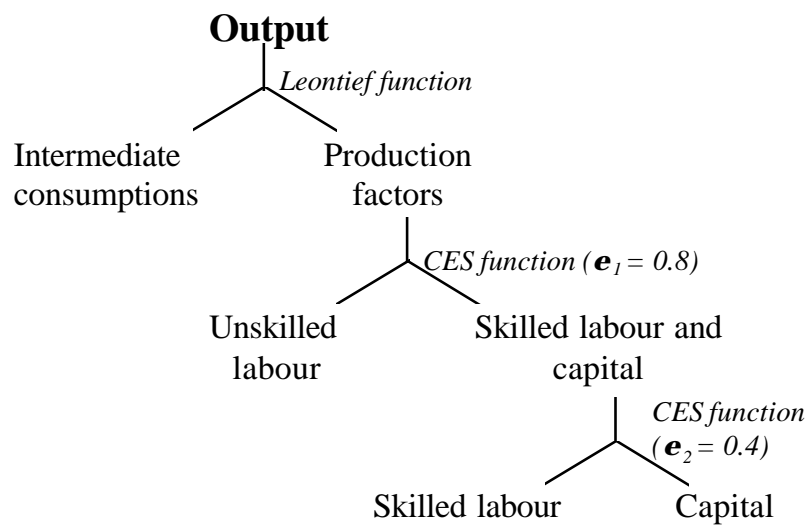


The combination of production factors is represented in two stages: a first CES function gathers unskilled labour and an aggregate of skilled labour and capital, the latter aggregate being represented though a CES with a lower elasticity of substitution. This aims at reflecting the relative complementarity between capital and skilled labour.

We set the elasticity of substitution between unskilled labour and the aggregate skilledcapital at 0.8 . This value may seem fairly low, as surveys like those by Freeman (1986) and Hamermesh $(1986,1993)$ suggest that it is not clear whether this elasticity should be superior or inferior to unity. However, Wood $(1994,1995)$ argues that commonly-used values are over-estimated, mainly because they are calculated using a very high level of aggregation for sectoral data. Consequently, the variations measured in factor intensities not only correspond to changes within-firms, but also to structural effects linked to changes in product-mix. Only the first effect should be taken into account in the context of a CGE model, where uniform factor intensity is assumed within each sector. The study of Legendre and Le Maître (1997) based on panel data for France confirms that taking into account interfirm heterogeneity leads to lowering the estimations of capital-labour substitutability, and estimates by Steiner and Wagner (1997) with disaggregated data for Germany point in the same direction. Nonetheless, we will consider in the sensitivity analysis the possibility for this elasticity to be superior to one (1.2).

The service sector is assumed to be perfectly competitive, while industrial sectors are in monopolistic competition à la Cournot (see Annex 1 for details). Given the substantial length of the period considered, and the fact that we focus on structural equilibria, the number of firms is assumed to be variable, and set by a zero-profit condition. Knowing fixed costs and the elasticity of substitution between goods, this zero-profit condition also enables the number of firms to be calibrated in the benchmarks.

\section{Trade flows}

The French demand for imports does not call for a specific modelling: it is set through the demand of French consumers, as a result of their utility maximisation under budget constraint. The demand addressed to French exports, in contrast, has to be modelled in an ad hoc way. This is done assuming that export intensity ${ }^{3}$ depends on the relative price of exports to imports with a constant elasticity, equal to the Armington elasticity of substitution used in the sub-utility index of the sector:

$$
\frac{Y_{\mathrm{Fr}, \mathrm{s}, \mathrm{j}}}{\mathrm{Y}_{\mathrm{Fr}, \mathrm{s}, .}}=\mathrm{CFC}_{\mathrm{s}}\left(\frac{\mathrm{p}_{\mathrm{Fr}, \mathrm{s}, \mathrm{j}}}{\mathrm{p}_{\mathrm{j}, \mathrm{s}, \mathrm{Fr}}}\right)^{-\hat{o}_{2, \mathrm{~s}}}
$$

\footnotetext{
${ }^{3}$ This modelling of the demand addressed to exports is based on export intensity, not on exports, basically because we want to take into account the growth of foreign markets. Through this formulae, we assume that foreign markets grow at the same rate than the domestic market. To put it another way: were we to choose a "norm" for exports evolution, we would define it as a constant export intensity, not as a constant volume of exports.
} 
Where the subscript $F r$ refers to France, $j$ to another area (North or South), and $s$ to an industrial sector ( $\mathrm{s}=1$ to 8 ). $Y_{\mathrm{Fr}, \mathrm{j}, \mathrm{j}}$ is the French output of sector $s$ sold in area $j$ as a final consumption, $p_{\mathrm{Fr}, \mathrm{s}, \mathrm{j}}$ is the corresponding price, and $p_{\mathrm{j}, \mathrm{s}, \mathrm{Fr}}$ is the price of French imports in the sector $s$, from area $j$. $Y_{\mathrm{Fr}, \mathrm{s}}$, is the total French output of sector $s$. $C F C_{\mathrm{s}}$ is a constant, calibrated on the basis of the French export flow of final consumptions in sector $s$. A similar equation can be written for intermediate consumptions, with a specific constant, $C I C_{\mathrm{s}} . \sigma_{2, \mathrm{~s}}$ is the Armington elasticity of sector $s$.

Prices of imports $\left(p_{\mathrm{j}, \mathrm{s}, \mathrm{Fr}}\right)$ are given in the database. In the simulations, two closing rules are possible with regards to foreign trade with: the first one is to consider these import prices as exogenous, hence an endogenous trade balance; the second one is to consider the trade balance as exogenous, and to allow import prices to vary by the same proportion for all sectors, which is equivalent to assume the exchange rate to be endogenous. Except where otherwise stated, this second closure rule will be adopted.

\section{Production factor markets}

The rise in unemployment, in particular among unskilled workers, has been one of the main features of the French economy during the last decades. However, it is difficult to account for it in a CGE model. Since we are concerned only with structural equilibrium, frictional and cyclical unemployment are irrelevant here. Only structural unemployment could be studied in this framework, but even in this case, some important problems arise. Let us assume, for example, that unskilled labour market can be described through a WS-PS model (as in Bontout and Jean, 1998, for example); the problem is that the WS curb would not be unchanged throughout the period studied, and that we cannot account explicitly for the determinants of this shift.

We therefore choose not to model explicitly unemployment. Instead, we try to account for the structural full-employment equilibrium underlying the benchmark. According to the OECD, the unemployment rate in France rose from $2.5 \%$ in 1970 to $10.4 \%$ in 1992 . We will assume that in terms of structural unemployment only, this rate rose from $0 \%$ in 1970 to $7 \%$ in 1992. Consequently, we consider the 1970 database to describe a full-employment equilibrium. For 1992, we assume that this unemployment hurts only unskilled workers, due to a misadjustment in relative wages. We then re-calculate the 1992 equilibrium, assuming that wages adjust in order to allow for full employment. Thus, all the changes we try to account for are expressed in terms of relative wages.

In this context, we can assume all factor markets to be perfectly competitive, with perfectly flexible price, included for unskilled labour. The supply of each production factor is assumed to be exogenous, and full employment of each factor is met through wage adjustment. 


\section{DECOMPOSITION ANALYSIS IN A GENERAL EQUILIBRIUM FRAMEWORK: METHODOLOGY}

\section{A. Structural model and state variables}

In order to describe the state of the economy at a given date, we initially need an extended database (see next section and Annex 2 for further details on the data), covering output, value added, production factors, intermediate consumptions and trade flows for each sector, plus the prices of goods and production factors. Once the structural model is chosen, however, the state of the economy can be summarised in a plainer fashion.

Indeed, we assume constant over time the parameters which are not calibrated, i.e. the elasticities of substitution between (baskets of) goods used in the utility function and the elasticities of substitution between factors in the production function, plus the magnitude of fixed costs as a proportion of total production costs, for industrial sectors. We also suppose that there is no trade barriers.

In this context, the state of the economy is fully determined by two categories of calibrated parameters and two categories of exogenous variables:

- share coefficients in the production function (calibrated parameters);

- share coefficients in the utility function (calibrated parameters);

- sector structure of relative import prices (i.e. $\left.p_{\mathrm{i}, \mathrm{s}, \mathrm{Fr}} / p_{\mathrm{i}, \mathrm{s}^{\prime}, \mathrm{Fr}}\right)$, plus the level of exchange rate (i.e. the level of one import price, relative to the domestic price in the same sector) or the level of trade balance (exogenous variables);

- factor supplies (in physical units, not in values) (exogenous variables).

\section{B. From state variables to decomposition analysis}

In other words, once the structural model is chosen, these four sets of values constitutes a set of state variables for the whole economy. Thus, as soon as the structural model is assumed to be unchanged, the structural change of the economy between two dates can be summarised through the changes in these state variables. And we can link the main causes put forward for the evolution in wage inequalities to these changes in state variables:

- technical change is summarised through the changes in the share coefficients in the production function (this does not allow to take into account the changes in quality nor the appearance of new products, but this is no surprise as long as we assume the structural model to be unchanged);

- changes in the sectoral distribution of (intermediate and final) consumers demand are reflected in the changes in the share coefficients in the upper tier of the utility function;

- trade evolutions are the consequence of both changes in import prices relative to domestic prices (and in the value of trade balance), and evolutions of the share coefficients in the Armington tier of the utility function (which reflect the geographical distribution of consumers demand, for given prices); 
- changes in factor supplies are directly accounted for.

This enables the contribution of each of these four main shocks to be determined: it is equal to the impact of the change in the corresponding set of state variables. The problem is that this impact depends on the initial state of the economy. The effect of the sum of these four shocks is known (it corresponds to the structural change observed between 1970 and 1992), but the impact of one of them is not the same if it is assumed to occur first (from the 1970 benchmark) or after other shocks. One way to overcome this problem could be to divide the period in many subperiods (the shorter the period, the weaker the dependence between the impact of a single shock and the order in which shocks are considered to occur), but this method would require a heavy data work. For the sake of simplicity, we adopt the following proxy. The impact of each shock (i.e. each change in a set of state variables) is computed assuming it occurs first (on the basis of the 1970 benchmark) and then assuming that it occurs after the three other shocks (in this case, the shock leads, from an intermediary state of the economy, to the 1992 benchmark $^{4}$ ). The proxy is the average of these two impacts. ${ }^{5}$

This procedure is fairly straightforward to implement in the case of factor supplies and of technical progress (i.e. share coefficients in the production function). It is somewhat more tricky, however, for the two other shocks (sectoral consumption pattern and international trade). The first reason it that they modify the utility function of consumers, and therefore the dual price index. In this case, we use as a price index the geometric average of the dual price indexes of the initial and final utility functions. The second problem is the linkage between the various tiers of the utility function.

\section{Accounting for changes in international trade intensities}

To determine the contribution of trade to the structural change of the French economy, we simulate the impact of a shock corresponding to the modification of the state variables reflecting the evolution of trade intensities (i.e. export intensity and import penetration rate) by sector.

For export intensity, the change is due to the evolution of French export prices, with respect to foreign prices (the latter are assumed to be equal to import prices), but also to the changes in the function of demand addressed to French exports, namely in the constant $C F C_{\mathrm{s}}$ (for final consumption, in sector $s$ ) and $C I C_{\mathrm{s}}$ (for intermediate consumption), which are changed from their 1970 value to their 1992 value.

In order to account for the changes in the import penetration rate, we first change the Armington tier of the utility function (turning from the share coefficients calibrated in 1970 to those obtained in 1992 , both for final and intermediate consumptions). In fact, these

\footnotetext{
${ }^{4}$ In practice, we start from 1992's benchmark, and assume that the state variables concerned take back their 1970's value. This gives the "intermediary state" of the economy mentioned above.

${ }^{5}$ If $\Delta_{\text {ini }}$ is the variation observed on a variable for the first simulation, and $\Delta_{\text {fin }}$ the variation observed for the second simulation, then the average will be $\left[\left(1+\Delta_{\text {ini }}\right)\left(1+\Delta_{\text {fin }}\right)\right]^{1 / 2}-1$.
} 
coefficients summarise many things: possible changes in consumers tastes, trade barriers, transport costs, access of importers to distribution networks, supply effects (increase in the number of varieties offered by importers, for example), etc. We do not try to disentangle these various effects.

Changing these "Armington coefficients" means that the composition of the sector baskets used in the upper tier is changed. In this context, the same share coefficients in the upper tier of the utility function would lead to a different distribution of consumption between sectors, simply because these coefficients apply to baskets the definition of which has changed. For the sake of coherence, it is therefore necessary to re-calibrate the share coefficients in the upper tier, in order to make sure that the sector distribution of consumption is not changed, for given prices. Once this is done, we take into account the changes in import prices.

To summarise, the "trade intensity shock" corresponds to a change in a set of state variables, which induces a shift of export intensities and import penetration rates, for each sector, from their 1970 level to their 1992 level. Concretely, the following state variables are changed (from their 1970 level to their 1992 level):

- import prices, with respect to domestic prices (as import prices are set, trade balance is supposed to be endogenous);

- constants in the function of demand addressed to French exports;

- share coefficients in the Armington-type sub-utility function of each industrial sector (with a re-calibration of the coefficient of the upper tier in coherence with the change in the composition of the sector goods' basket).

\section{Accounting for changes in the sector distribution of consumption}

In order to account for the changes in the sector distribution of consumption, we change the value of the share coefficients in the upper tier of the utility function, from their 1970's level to their 1992's level. But the definition of the baskets of goods concerned is not the same in both cases. It is therefore inconsistent to change the coefficients of the upper tier without taking into account the shift occurred at the lower (Armington) level.

To overcome this problem, we assess the global effect of trade and sector distribution of consumption (changing the whole utility function from its 1970's expression to its 1992's expression, and taking into account the changes in coefficients of demand addressed to exports, and in import prices), taken together. The effect of the shift in the sector distribution of consumption alone is then obtained by difference with the effect of changes in trade intensities. ${ }^{6}$

\footnotetext{
${ }^{6}$ This is a proxy, because it assumes that changes in the sector distribution of consumption always occur after changes in trade. As we will see, however, the impact of trade is rather low. As a consequence, the fact to assume it to occur after changes in trade does not change too much the impact of variations in the sector distribution of consumption.
} 


\section{THE RESULTS}

\section{A. Stylised facts}

The data used are drawn from French National Accounts (see details in Annex 2). For each good and for each production factor, the physical unit used is the same in both databases (the evolutions expressed in volumes are set on the basis of 1980 prices) ${ }^{7}$. The prices are all set to unity ${ }^{8}$ in the calibration of the 1970 benchmark, as usual, but this is not the case for the calibration of the 1992 benchmark, as we account for variations in prices (note however, that only real values are relevant here, i.e. that the numeraire can be chosen freely in the second calibration).

The main evolutions are summarised in Table 2. Note in particular that the real ${ }^{9}$ wage for unskilled workers ${ }^{10}$ has been rising faster $(+51 \%$ over the period) than the real wage for skilled workers $(+33 \%)$. But, as mentioned above, we do not use the 1992 database directly as the final benchmark: we first compute an "underlying full-employment structural equilibrium", assuming that the economy (and in particular wages) adjusts in order to remove the $7 \%$ structural unemployment. Once this is done, we observe that the relative competitive wage ${ }^{11}$ of skilled to unskilled workers hardly changed over the period: it slightly increased, from 2.23 in 1970 to 2.24 in 1992, and the real wage is found to have increased by about $40 \%$ for both categories. On the other hand, the employment growth is very different for these two categories: while skilled employment increased sharply (+65\%), unskilled employment declined $(-12.1 \%$ before adjustment for unemployment, $-2.4 \%$ after). As computed from the evolution of global income of capital and from the very strong increase in the net fixed capital stock $(+147 \%)$, the real cost of capital is found to have decreased by $18 \%$ before adjustment for unemployment, and by $13 \%$ after the adjustment.

Meanwhile, trade intensities have risen sharply in the tradable sectors. The average import penetration rate (imports over total domestic demand) from the South nearly doubled (3.2 to $6.1 \%$, and the increase would be far higher, were we to exclude energy), while it rose from 9.3 to $15.8 \%$ for imports from the North. The average export intensity went up from 3.6 to $6.8 \%$ toward the South, and from 8.2 to $14.9 \%$ toward the North. Of course, given the increasing weight of services, the evolutions are less impressive for the economy as a whole, but still the average import penetration rate rose from $7.2 \%$ to $9.8 \%$, and the export intensity went up from $6.8 \%$ to $9.7 \%$.

\footnotetext{
${ }^{7}$ For capital stock, we use the estimates made by the French national statistical institute (INSEE) of the net, fixed capital stock by industry.

${ }^{8}$ This is only a particular way to choose the physical unit, for each good and for each factor.

${ }^{9}$ In this descriptive comment, real values are calculated on the basis of GDP deflator.

10 "Employés" and "ouvriers", in the French classification. Skilled workers, in contrast, are those classified as intermediate and superior professions.

${ }^{11}$ In fact, the data refers to labour cost, not to net or gross wages.
} 
The initial data set also enables the evolution of partial productivities to be observed. Their average over the whole economy reflects mostly the relative rhythm of accumulation of each factor, in comparison of GDP growth. It is no surprise, in this context, to observe a sharp fall in the average partial productivity of capital $(-30 \%)$, while skilled labour partial productivity slightly increases $(+5 \%)$, and the average partial productivity of unskilled workers is nearly doubled $(+98 \%)$.

Table 2: Descriptive analysis from the 1970 and 1992 databases

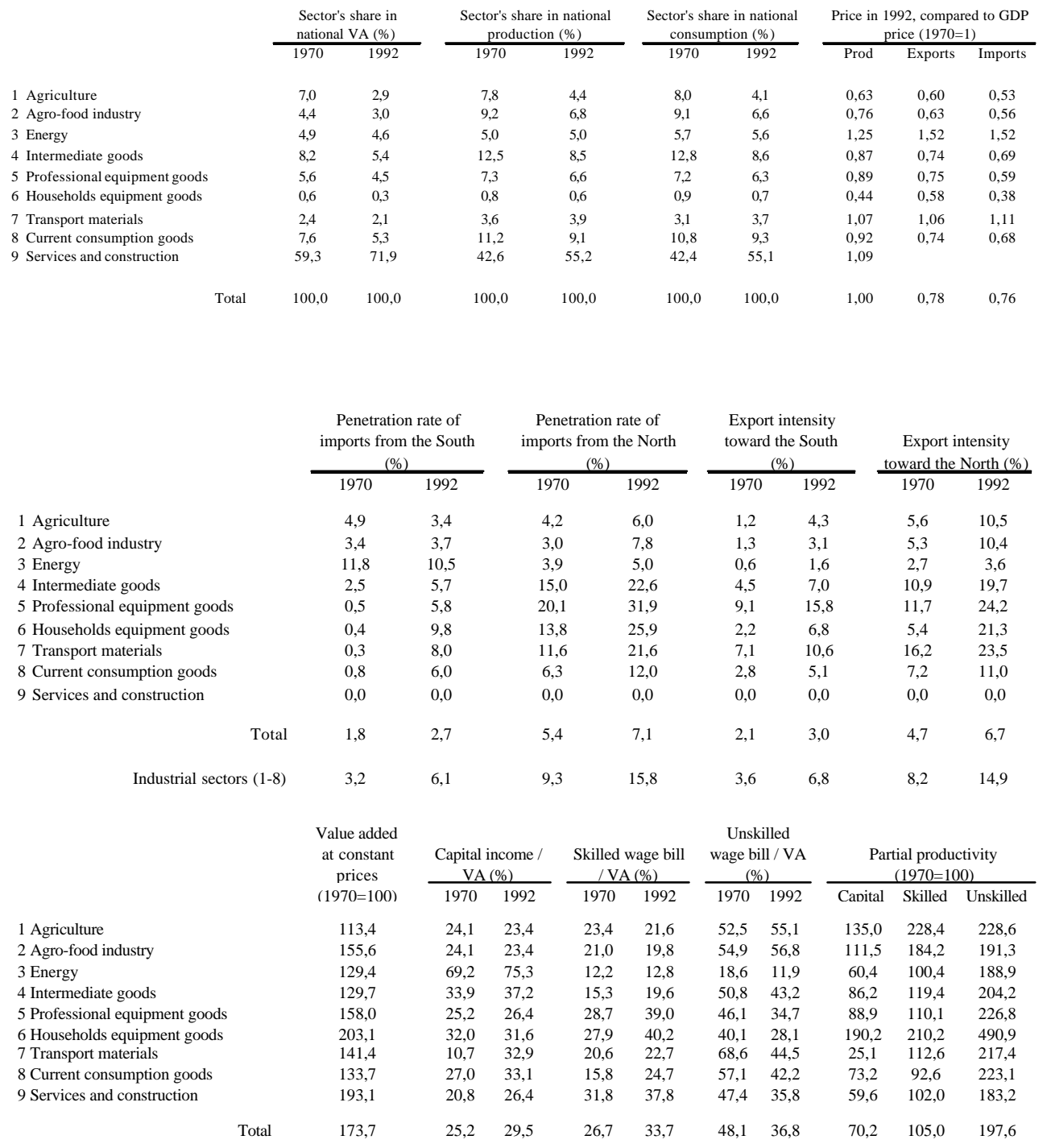




\section{B. Results of the decomposition analysis}

The results of the decomposition analysis are reported in Table 3. Note first that the global change reported in this table (line (a), obtained by changing all state variables from their 1970 value to their 1992 value, and taking into account the change in the trade balance) differs from the changes described above. This is due mainly to differences in price measures: the model measures prices variations through dual price indexes, instead of the chained Laspeyres indexes used in the national accounts; moreover, we use a consumer price index in the model, instead of a GDP deflator in the data mentioned above, and the former increased less than the latter (see below). As a result, the consumer price index increase measured over the period is around $8 \%$ lower following the model than in the data. Consequently, the global changes observed in the simulation for real values are around $8 \%$ higher than in the benchmark. ${ }^{12}$

Table 3: Decomposition analysis for France, 1970-1992

\begin{tabular}{|c|c|c|c|c|c|}
\hline & & & iation in real wa & & \\
\hline & & Unskilled & & & $\begin{array}{l}\text { Variation in skilled / } \\
\text { unskilled relative }\end{array}$ \\
\hline & Welfare & labour & Skilled labour & Capital & wage \\
\hline Global change (a) & 95,6 & 49,9 & 52,5 & $-8,2$ & 1,7 \\
\hline Contribution of : & & & & & \\
\hline Technical change (b) & 37,0 & $-6,5$ & 30,5 & 162,5 & 39,5 \\
\hline Factor supplies (c) & 58,3 & 82,5 & 19,0 & $-57,3$ & $-34,8$ \\
\hline Trade $(\mathrm{d})$ & 6,2 & 4,6 & 5,6 & 4,5 & 1,0 \\
\hline Consumption (e) & $-14,2$ & $-14,9$ & $-4,8$ & $-22,8$ & 11,8 \\
\hline Resulting effect (f) & 97,5 & 51,9 & 56,2 & $-9,5$ & 2,8 \\
\hline Residual (g) & $-1,0$ & $-1,3$ & $-2,4$ & 1,4 & $-1,1$ \\
\hline
\end{tabular}

Note: All figures are variations in percentage. The resulting effect is calculated as $(\mathrm{f})=($ $1+(\mathrm{b})) \times(1+(\mathrm{c})) \times(1+(\mathrm{d})) \times(1+(\mathrm{e}))-1$, and the residual is $(\mathrm{g})=(1+(\mathrm{a})) /(1+(\mathrm{f}))-1$.

Applying the methodology described above makes it possible to decompose this global change, with a fairly good global fit: the residual between the resulting effect of the four shocks and the global effects is inferior to $2.5 \%$ for each variable. Technical change and variations in factor supplies appears to be by far the most important contributors to the global change, be it in terms of welfare or in terms of real and relative wages. These two shocks have had a strong positive impact on welfare, but its distribution among factors is very different. Not surprisingly, variations in factor supplies seem to have been very favourable to unskilled real wage (the only factor whose stock decreased) and very

\footnotetext{
12 Even taking this into account, the matching between the global results and observe variations is not perfect, but the difference is always inferior to $2 \%$. These differences are linked to the treatment of monopolistic competition, because fixed costs have been set at the same share of total cost in both benchmarks. This should probably be modified in a future version.
} 
unfavourable to the real reward for capital, whose accumulation was very rapid. The effect on skilled real wage is intermediary, so that this shock have had a strong negative effect ($34.8 \%$ ) on the skilled to unskilled relative wage. This effect is more than balanced by the impact of technical change, which increased the relative wage of skilled workers by nearly $40 \%$, with a negative effect $(-6.5 \%)$ on unskilled real wage.

The variation in the sectoral distribution of demand corresponds mainly, in fact, to a shift toward services. As this sector is the only one with constant returns to scale, the impact on welfare turns out to be negative. Moreover, as services are more skilled-intensive and less capital-intensive than the average, this shock is very unfavourable to capital real reward $(-22.8 \%)$, but it has a weak effect on skilled real wage $(-4.8 \%)$. The impact on unskilled real wage is intermediary $(-14.9 \%)$. Consequently, it increases the skilled to unskilled relative wage by $11.8 \%$.

By comparison, the effect of trade seems to be rather weak. More importantly, perhaps, it is the only shock to have a positive effect on the real cost of each of the three production factors, including unskilled labour $(+4.6 \%)$. There are gains linked to product differentiation and economies of scale, but the Stolper-Samuelson effect is most of all dominated by the strong improvement in terms of trade (nearly $+20 \%$ ). This is problematic, however. It is true that import prices rose less rapidly than domestic production prices, but we do not take into account here the other side of the coin: export prices rose even less rapidly. As long as we assimilate export prices to production prices (with only a small difference linked to markups), we cannot account for this stylised fact.

Still, trade increases the skilled to unskilled relative wage by $1 \%$, but this effect is quite negligible compared to the other impacts mentioned above. It is arguable, however, that the weak sectoral breakdown used here underestimates the variations in specialisation, in particular concerning trade with Southern countries.

\section{The link between trade and productivity}

The decomposition analysis presented above assumes that the different shocks studied above are independent (although their consequences are not, as we have emphasised). In particular, we assumed that technical change is independent from variations in trade intensities. This is not what some recent studies argue. Be it through defensive innovation, through decreasing $\mathrm{X}$-inefficiencies, through technological catch-up or through firm selection, an increase in trade intensity may modify the production function of the representative firm of each industry, spurring productivity and inducing skill-upgrading. Empirical evidence supporting this link has been found by Hine and Wright (1995), Feenstra and Hanson (1996), ${ }^{13}$ Cortes and Jean (1997) and Greenaway, Hine and Wright (1999). The validity of these results is questionable, but the set-up presented here enables the stakes of such a relationship to be clarified.

\footnotetext{
${ }^{13}$ Feenstra and Hanson focus on foreign outsourcing, but their results also show an impact of import penetation rate on the share of unskilled workers in the wage bill.
} 
If such an impact of trade intensity variations on productivity holds, this means that changes in factor productivities have to be split in two components: one which is linked to trade, and another which is "autonomous". In this case, only the latter belongs to the contribution of technical change, in our decomposition analysis. The former, in contrast, is part of the contribution of variation in trade intensities. This means that the joint impact of trade and technology is unchanged, but that we need to reassess the respective contributions of these two shocks.

In order to include it in the model, we use here the empirical results of Cortes and Jean (1997). They had shown that a one point increase in the import penetration rate in a given industry induces a $1.3 \%$ increase in the partial productivity of labour in this industry if imports come from the South and a $0.7 \%$ increase if they come from the North. They also found an effect on labour skill: a one point increase in the import penetration rate induces a $0.4 \%$ increase in the skilled to unskilled ratio in the industry concerned. In other words, the effect is stronger on the partial productivity of unskilled labour than on the productivity of skilled labour. Formally, this effect is modelled through an endogenous impact of the import penetration rate variations on the parameters of the production function of the representative firm, industry by industry. We will assume, in addition, that import penetration variations have the same impact on the productivity of capital than on the productivity of skilled labour (see Annex 3 for further details).

The results of the reassessment of the contributions of trade and technology are reported in Table 4. The impact of trade is strongly increased when an effect on productivity is assumed to hold, and it induces a welfare increase $(+17.1 \%)$ not far from the one obtained for technical change $(+22.8 \%)$. Once again, trade appears in this case to have had a positive impact on the real cost of each production factor, included for unskilled workers $(+13.5 \%)$.

Table 4 : Contributions of trade and technical change, with and without trade-induced effect on productivities

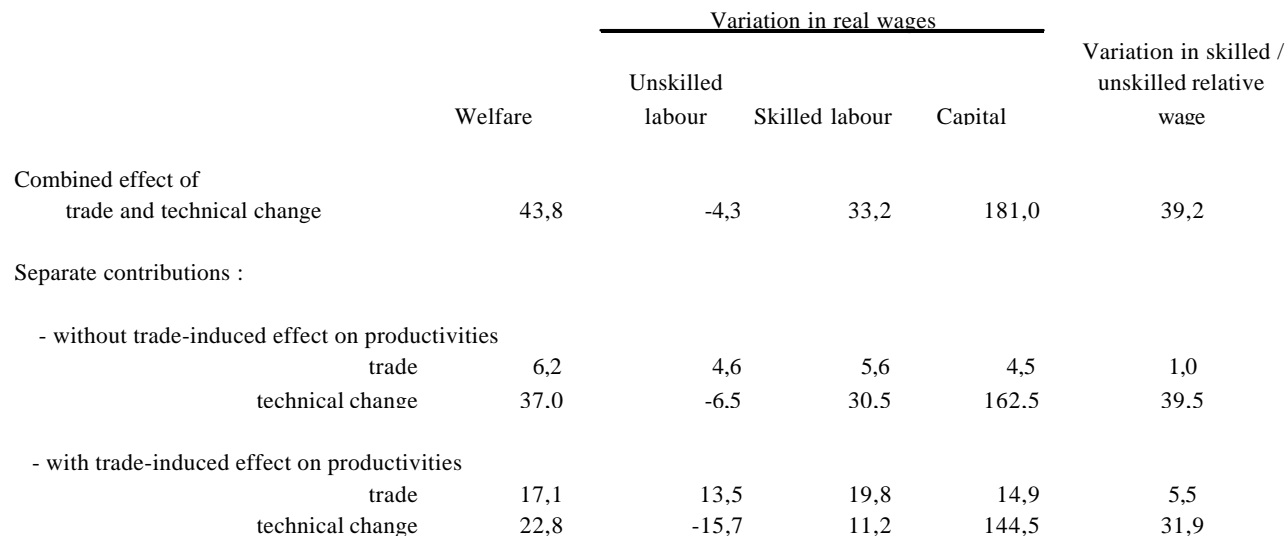


Note: All figures are variations in percentage. The composition of both effect is exactly equal to the combined effect in the case "with trade-induced effect on productivities", by construction. It is not the case for the contributions "without...", because the contributions have been calculated as in the previous section (average of the effects obtained assuming that the shock is the first / the last to occur).

However, its influence on the skilled to unskilled relative wage is then positive and significant $(5.5 \%)$. Of course, this effect is weak compared to the impact of trade or factor supplies variations. But this direct comparison is not necessarily the most relevant: it is normal, according to secular trends, to observe an increase in the skilled to unskilled relative supply, and a parallel decrease in the partial productivity of skilled workers, compared to that of unskilled workers. An evolution in wage inequalities occurs when these trends turn out not to be "parallel". In this perspective, the 5.5\% impact of trade on relative wages is far from being negligible.

\section{Sensitivity to the substitutability between production factors}

The decomposition analysis presented above depends on the parameters chosen in the model, on the basis of external information. These parameters include the magnitude of fixed costs in French industrial sectors, the elasticities used in the demand addressed to French exports, and the elasticities used in the utility function (describing the substitution between sectors, between products from different geographical origins, and between French varieties). The most sensitive, however, are the elasticities used in the production function (describing the substitution between production factors).

In particular, we know a priori that the effect of a given factor bias in technical change depends on how the elasticity of substitution between the factors concerned compares to unity (see for example Cotis, Germain and Quinet, 1997). So far, the elasticity of substitution has been set to 0.4 between capital and skilled labour, and to 0.8 between their aggregate and unskilled labour. We explained above why we chose these values, but it is worth studying how the results change when a higher substitutability between factors is assumed. This is why we re-assessed the decomposition analysis presented above assuming these two elasticities to be equal to 0.8 and 1.2 , respectively (see Table 5). 
What Drove Relative Wages in France? Structural Decomposition Analysis in a General Equilibrium Framework, 1970-1992

Table 5:

Decomposition analysis for France, 1970-1992, with a high substitutability between factors $\left(\sigma_{1}=1.2\right.$ and $\left.\sigma_{2}=0.8\right)$

\begin{tabular}{|c|c|c|c|c|c|}
\hline & \multirow{2}{*}{ Welfare } & \multicolumn{3}{|c|}{ Variation in real wages } & \multirow[b]{2}{*}{$\begin{array}{c}\text { Variation in skilled / } \\
\text { unskilled relative } \\
\text { wage }\end{array}$} \\
\hline & & $\begin{array}{l}\text { Unskilled } \\
\text { labour }\end{array}$ & Skilled labour & Capital & \\
\hline Global change (a) & 95,7 & 54,2 & 49,0 & $-8,9$ & $-3,4$ \\
\hline \multicolumn{6}{|l|}{ Contribution of : } \\
\hline Technical change (b) & 38,2 & 14,8 & 49,4 & 71,2 & 30,2 \\
\hline Factor supplies (c) & 57,1 & 52,0 & 6,1 & $-37,8$ & $-30,2$ \\
\hline Trade $(\mathrm{d})$ & 6,2 & 4,6 & 5,3 & 4,7 & 0,6 \\
\hline Consumption (e) & $-14,2$ & $-14,7$ & $-9,4$ & $-18,6$ & 6,2 \\
\hline Resultant effect (f) & 97,7 & 55,8 & 51,1 & $-9,3$ & $-3,0$ \\
\hline Residual (g) & $-1,0$ & $-1,0$ & $-1,4$ & 0,5 & $-0,4$ \\
\hline
\end{tabular}

Note first that the global change to explain is not exactly the same as previously. This is not surprising, as long as we do not use directly the 1992 data set as a benchmark: we assume first that relative wages adapt in order to remove structural unemployment. The corresponding adjustment is less important when the substitutability between production factors is higher. Here, it involves a $8.8 \%$ increase in the skilled to unskilled relative wage. As a consequence, the variation to be explained in this relative wage is a slight decrease ($3.4 \%)$.

Compared to the previous results, the outcome of the decomposition analysis is not fundamentally changed. The contributions of both factor supplies and technical change is weakened, but they remain important and of the same order of magnitude (the resultant of these two effects is negative, however: recall that these variations are not to be summed directly). The impact of the shift in the sectoral distribution of consumption on welfare and factor incomes is still negative, though its positive impact on skilled relative wage is halved. The contribution of trade is nearly unchanged.

This good robustness with regards to factors' substitutability can be considered as surprising, most of all concerning the impact of technical change. It is due mainly to the fact that the definition of the corresponding shock has to be changed, consistently with the new elasticities. The share coefficients in the production function are not the same when the elasticities of substitution used in this function change: it is necessary to make a new calibration, in order to re-calculate the value of these coefficients both in 1970 and in 1992 .

\section{CONCLUSION}


In this paper, we confront a CGE model to observed evolutions in France, between 1970 and 1992, through a decomposition analysis. We start by observing that, once the structural model is chosen, and constant elasticities of substitution are assumed over time, both in the utility function and production function, the change of the economy between two equilibria can be summarised through the changes in a set of four types of state variables: share coefficients in the production function, reflecting the productivity for each factor within each sector; factor supplies, assumed to be exogenous; share coefficients in the utility function, reflecting the preferences of consumers; and, for each sector, the relative price of imports, as a proportion of domestic output price.

The separate simulation of the impact of the change observed in each of these four sets of state variables then provides an assessment of the specific contribution of each underlying cause: technical change, changes in factor supplies, shifts in consumption patterns, and international trade. These various causes are then assessed in a unified and consistent framework, with the constraint of explaining the whole evolution observed.

The model distinguishes three production factors (unskilled labour, skilled labour and capital), and nine sectors. It uses the Armington hypothesis, but also incorporates horizontal differentiation, monopolistic competition and economies of scale for French industrial sectors.

The ratio of skilled to unskilled competitive wage barely changed between 1970 and 1992 in France. However, we conclude that technical change had a strong positive effect on skilled relative wage, more than counterbalanced by the negative effect of changes in factor supplies. These two effects are by far the most important, and they mainly reflect the secular skill upgrading of industrialised economies.

The shift in consumption patterns, away from industrial goods towards services, increased substantially the skilled relative wage. International trade also increased wage inequalities, but its effect is very weak, at least with a standard formulation. Moreover, it had a positive effect on the real income of each factor, including unskilled labour, mainly because import prices decreased, compared to domestic output prices. Nevertheless, if we take into account the trade-induced effect on productivity measured in some recent studies, we find that trade substantially increased the relative wage of skilled to unskilled workers. 
What Drove Relative Wages in France? Structural Decomposition Analysis in a General Equilibrium Framework, 1970-1992

\section{REFERENCES}

Bontout O. and Jean S. (1998), "Wages and Unemployment: Trade-off Under Different Labour Market Paradigms", Research Paper, n 99/6, GLM, University of Nottingham.

Cardebat J.-M. and Teï letche J. (1997), "Salaires relatifs, commerce Nord-Sud et progrès technique : un modèle stylisé d'équilibre général calculable", in Commerce Nord-Sud, migration et délocalisation - Conséquences pour l'emploi et les salaires, edited by $\mathrm{J}$. de Melo and P. Guillaumont, Economica, Paris, pp. 183-206.

Cortes O. and Jean S. (1996), "Pays émergents, emploi déficient ?", Document de travail, $\mathrm{n}^{\circ}$ 96-05, CEPII.

Cortes O. and Jean S. (1997), "Quel est l'impact du commerce extérieur sur l'emploi ? Une analyse comparée des cas de la France, de l'Allemagne et des Etats-Unis", Document de travail, $\mathrm{n}^{\circ}$ 97-08, CEPII, and Document d'études, $\mathrm{n}^{\circ}$ 13, DARES.

Cortes O. and Jean S. (1998), "Does Competition of Emerging Countries Threaten the European Unskilled Labour? An Applied General Equilibrium Approach", in Global Trade and European Workers, édité par P. Brenton and J. Pelkmans, Macmillan, Londres, pp. 96-122.

Cortes O. and Jean S. (2000), "Trade Spurs Productivity", in Globalisation and Employment Patterns, edited by J. Francois, D. Roland-Holst and D. van der Mensbrugghe, Oxford University Press, forthcoming.

Cotis J.-Ph., Germain J. M. and Quinet A. (1997), "Les effets du progrès technique sur le travail peu qualifié sont indirects et limités", Economie et Statistique, n 301-302, pp. 23 44.

Feenstra R. C. and Hanson G. H. (1996), "Globalization, Outsourcing and Wage Inequality", American Economic Review, vol. 86, n² 2, pp. 240-245.

Freeman R. B. (1986), "Demand for Education", in Handbook of Labor Economics, vol. 1, edited by O. C. Ashenfelter and R. Layard, North-Holland, Amsterdam.

Gasiorek M., Smith A. and Venables A. (1992), "1992 Trade and Welfare: a General Equilibrium Model", dans Trade Flows and Trade Policies, edited by L. A. Winters, Cambridge University Press, Cambridge.

Greenaway D., Hine R. C. and Wright P. (1999), "An Empirical Assessment of Impact of Trade on Employment in the UK", European Journal of Political Economy, $\mathrm{n}^{\circ} 508$.

Hamermesh D. S. (1986), "The Demand for Labor in the Long Run", in Handbook of Labor Economics, vol. 1, edited by O. C. Ashenfelter and R. Layard, Amsterdam : NorthHolland, pp. 429-471. 
Hamermesh D. S. (1993), Labor Demand, Princeton University Press.

Hine R. C. and Wright P. (1995), "The Impact of Changing Trade Patterns on the Demand for Labour in the United Kingdom", mimeo, University of Notthingham, nov.

Jean S. and Bontout O. (1998), "Sensibilité des salaires relatifs aux chocs de commerce international et de progrès technique, une évaluation d'équilibre général", Document de travail, CEPII, nº 98-09.

Lawrence R. Z. and Evans C. L. (1996), "Trade and Wages: Insights from the Crystal Ball", Working Paper Series, ${ }^{\circ}$ 5633, NBER.

Legendre F. and Le Maître P. (1997), "Le lien emploi-coût relatif des facteurs de production : quelques résultats obtenus à partir des données de panel", Economie et statistique, $\mathrm{n}^{\circ} 301-302$, pp. 111-127.

Mercenier J. (1992), "Can '1992' Reduce Unemployment in Europe? On Welfare and Employement Effects of Europe's Move to a Single Market", Discussion Paper 2292, C.R.D.E., Université de Montréal.

Rowthorn R. (1995), "A Simulation Model of North-South Trade", UNCTAD Discussion Paper, $\mathrm{n}^{\circ} 104$.

Steiner V. and Wagner K. (1997), "Relative Earnings and the Demand for Unskilled Labour in West German Manufacturing", Discussion Paper, n 97-17, ZEW, Mannheim. 


\section{ANNEX 1: MODELLING IMPERFECT COMPETITION IN INDUSTRIAL SECTORS}

In the French industrial sectors ( $\mathrm{s}=1$ to 8 ), firms compete à la Cournot, and their mark-up ratio on a given market is defined by (the index for the market is omitted, for the sake of simplicity): ${ }^{14}$

$$
\mathrm{EP}=-\frac{\partial \mathrm{y}}{\partial \mathrm{p}} \frac{\mathrm{p}}{\mathrm{y}} \text { et } \mathrm{p}\left(1-\frac{1}{\mathrm{EP}}\right)=\mathrm{Cm}
$$

Where $p_{i}$ is the selling price and $C m_{i}$ the marginal cost of firm $i$. The firm's perceived priceelasticity $E P_{i}$ depends on its market share $\left(s_{i}\right)$ as follows:

$$
\frac{1}{\mathrm{EP}_{\mathrm{i}}}=\frac{1}{\mathrm{o}_{3}}+\left(\frac{1}{\mathrm{o}_{2}}-\frac{1}{\mathrm{o}_{3}}\right) \frac{1}{\mathrm{n}_{\mathrm{Fr}}}+\left(1-\frac{1}{\mathrm{o}_{2}}\right) \frac{\mathrm{p}_{\mathrm{i}} \mathrm{Y}_{\mathrm{i}}}{\mathrm{pp}_{\mathrm{s}} \mathrm{US}_{\mathrm{s}}}
$$

Where $\sigma_{2}$ is the Armington elasticity of substitution, and $\sigma_{3}$ is the elasticity of substitution between French varieties in the industry. ${ }^{15} \mathrm{n}_{\mathrm{Fr}}$ is the number of French firms in the industry (we assume a one-to-one correspondence to hold between firms and varieties), $Y_{i}$ is the ouput of firm i, and $\mathrm{pp}_{\mathrm{s}} \mathrm{US}_{\mathrm{s}}$ is the amount of consumption in sector $\mathrm{s}$, in the market concerned. The last term is omitte on foreign market, which is equivalent to assume that the market share of French exporters on foreign markets is negligible.

\footnotetext{
${ }^{14}$ We assume zero conjectural variations, and we do not take into account any Ford effect.

${ }^{15}$ For more details on Equation (2), see Gasiorek, Smith and Venables (1992), or Cortes and Jean (1996).
} 


\section{ANNEX 2: THE DATA}

Most of the data (I/O tables, in particular) are drawn for the time-series of the French national accounts, in the 1980's basis. This is the reason why 1992 is chosen as the last year: the sectoral data for value added, intermediate consumptions and labour compensation is not available for more recent years.

Some hypotheses have to be made for the sake of simplicity and coherence. Stocks variations and investments are considered as final consumptions. Trade flows in services are not taken into account, implying a correction in the final consumption for the service industry. Moreover, the data concerning factor intensities in the national accounts are not fully satisfactory. Some corrections have thus been made on the basis of the factor intensities given in the database built by the OFCE for its model MOSAIC.

The geographical distribution of trade is drawn from the Cepii-Chelem database, keeping the value of total trade for each sector equal to its value in the national accounts.

The data concerning labour skill are taken from the survey Enquête sur la structure de l'emploi (INSEE). The labour cost for skilled labour and for unskilled labour are built on the basis of the net earnings from the Déclaration Annuelles de Données Sociales (DARES and INSEE), adding social premiums. 


\section{ANNEX 3: MODELING THE TRADE-INDUCED EFFECT ON PRODUCTIVITY}

The aggregate of production factors (see also Figure 2) is expressed as follows (the index for the firm is omitted):

$$
\left.P F=\left[\tilde{a}_{U L} U^{\frac{\frac{a_{1}-1}{a_{1}}}{a_{1}}}+\tilde{a}_{S L K} S_{L K}\right]^{\frac{a_{1}-1}{a_{1}}}\right]^{\frac{a_{1}}{a_{1}-1}}
$$

Where $P F$ is the aggregate of production factors used by the firm, $U L$ is the input in unskilled labour, $S K L$ the input in the aggregate of skilled labour and capital. The $\gamma$ are the share coefficients of these two inputs.

The cost minimisation then leads to:

$$
\frac{\mathrm{VA}}{\mathrm{UL}}=\mathrm{p}_{\mathrm{FP}} \tilde{\mathrm{a}}_{\mathrm{UL}}^{-\mathrm{a}_{1}}\left(\frac{\mathrm{w}_{\mathrm{UL}}}{\mathrm{p}_{\mathrm{FP}}}\right)^{\mathrm{a}_{1}}
$$

Where $p_{\mathrm{FP}}$ is the dual index price of the aggegate $F P$, and $w_{\mathrm{UL}}$ is the unskilled wage. A similar relationship could written for $S K L$, the aggregate of skilled labour and capital, instead of unskilled labour.

For given prices, the partial productivity of skilled labour is thus proportional to $\tilde{\mathrm{a}}_{\mathrm{UL}}{ }^{-\AA_{1}}$. This makes it possible to include in the model the empirical results of Cortes and Jean (1997). They had shown that a one point increase in the import penetration rate in a given industry induces a $1.3 \%$ increase in the partial productivity of labour in this industry if imports come from the South and a $0.7 \%$ increase if they come from the North. They also found an effect on labour skill: a one point increase in the import penetration rate induces a $0.4 \%$ increase in the skilled to unskilled ratio in the industry concerned. In other words, the effect is stronger on the partial productivity of unskilled labour than on the productivity of skilled labour. We will assume, in addition, that import penetration variations have the same impact on the productivity of capital than on the productivity of skilled labour. Formally, this effect is modelled as the following endogenous setting of the parameters $\gamma$ : 


$$
\begin{aligned}
& -\AA_{1}\left(\ln \left(\tilde{a}_{U L}\right)-\ln \left(\tilde{a}_{U L}^{i n i}\right)\right)=\left(0.013+0.004 \frac{S K L}{S K L+U L}\right)\left(M P_{\text {South }}-M_{\text {South }}{ }_{\text {ini }}\right) \\
& +\left(0.007+0.004 \frac{\mathrm{SKL}}{\mathrm{SKL}+\mathrm{UL}}\right)\left(\mathrm{MP}_{\text {South }}-\mathrm{MP}_{\text {South }} \text { ini }\right)
\end{aligned}
$$

and

$$
\begin{gathered}
-\stackrel{a}{1}_{1}\left(\ln \left(\tilde{\mathrm{a}}_{\mathrm{SLK}}\right)-\ln \left(\tilde{\mathrm{a}}_{\mathrm{SLK}}{ }^{\mathrm{ini}}\right)\right)=\left(0.013-0.004 \frac{\mathrm{SKL}}{\mathrm{SKL}+\mathrm{UL}}\right)\left(\mathrm{MP}_{\text {South }}-\mathrm{MP}_{\text {South }}{ }^{\mathrm{ini}}\right) \\
+\left(0.007-0.004 \frac{\mathrm{SKL}}{\mathrm{SKL}+\mathrm{UL}}\right)\left(\mathrm{MP}_{\text {South }}-\mathrm{MP}_{\text {South }}^{\text {ini }}\right)
\end{gathered}
$$

Where $M P$ refers to the penetration rate of imports from the zone indicated by the subscript. The superscript "ini" refers to initial values. 
What Drove Relative Wages in France? Structural Decomposition Analysis in a General Equilibrium Framework, 1970-1992

\section{LIST OF WORKING PAPERS RELEASED BY CEPII ${ }^{16}$}

\section{0}

"Le passage des retraites de la répartition à la capitalisation obligatoire : des simulations à l'aide d'une maquette", O. Rouguet and P. Villa, working paper $n^{\circ} 00-02$, January.

"Rapport d'activité 1999", working paper n 00-01, January.

\section{9}

"Exchange Rate Strategies in the Competition for Attracting FDI", A. Bénassy-Quéré, L. Fontagné and A. Lahrèche-Révil, working paper $n^{\circ}$ 99-16, December.

"Groupe d'échanges et de réflexion sur la Caspienne. Recueil des comptes-rendus de réunion (déc. 97-oct. 98)", D. Pianelli and G. Sokoloff, working paper $n^{\circ}$ 99-15, November.

"The Impact of Foreign Exchange Interventions: New Evidence from FIGARCH Estimations", M. Beine, A. Bénassy-Quéré and C. Lecourt, working paper $n^{\circ}$ 99-14, September.

"Forum Economique Franco-Allemand Deutsch-Französisches Wirtschaftspolitisches Forum", Reduction of Working Time/Eastward Enlargment of the European Union, $5^{\text {th }}$ meeting, Paris, July 6-7 1999", working paper $n^{\circ}$ 99-13, September.

"A Lender of Last Resort for Europe", M. Aglietta, working paper $n^{\circ}$ 99-12, September. OUT-OF-PRINT

"La diversité des marchés du travail en Europe : Quelles conséquences pour l'Union Monétaire ; Deuxième partie : Les implications macro-économiques de la diversité des marchés du travail", L. Cadiou, S. Guichard and M. Maurel, working paper $n^{\circ}$ 99-11, June.

"La diversité des marchés du travail en Europe : Quelles conséquences pour 1'Union Monétaire ; Première partie : La diversité des marchés du travail dans les pays de l'Union Européenne", L. Cadiou and S. Guichard, working paper $n^{\circ}$ 99-10, June.

"The Role of External Variables in the Chinese Economy; Simulations from a macroeconometric model of China", S. Dees, working paper $n^{\circ}$ 99-09, June.

\footnotetext{
${ }^{16}$ Working papers are circulated free of charge as far as stocks are available; thank you to send your request to CEPII, Sylvie Hurion, 9 rue Georges Pitard, 75015 Paris, or by fax (33) 0153685504 or by e-mail Hurion@cepii.fr. CEPII is also on the Web : http://www.cepii.fr.
} 
"Haute technologie et échelles de qualité : de fortes asymétries en Europe", L. Fontagné, M. Freudenberg and D. Ünal-Kesenci, working paper $n{ }^{\circ} 99-08$, June.

"The Role of Capital Accumultion, Adjustment and Structural Change for Economic TakeOff: Empirical Evidence from African Growth Episodes", J.C. Berthélemy and L. Söderling, working paper $n^{\circ}$ 99-07, April.

"Enterprise Adjustment and the Role of Bank Credit in Russia: Evidence from a 420 Firm's Qualitative Survey", S. Brana, M. Maurel and J. Sgard, working paper $n^{\circ}$ 99-06, April.

"Central and Eastern European Countries in the International Division of Labour in Europe", M. Freudenberg and F. Lemoine, working paper $n^{\circ}$ 99-05, April.

"Forum Economique Franco-Allemand - Economic Policy Coordination $-4^{\text {th }}$ meeting, Bonn, January 11-12 1999", working paper n 99-04, April.

"Models of Exchange Rate Expectations : Heterogeneous Evidence From Panel Data", A. Bénassy-Quéré, S. Larribeau and R. MacDonald, working paper n99-03, April.

"Forum Economique Franco-Allemand -Labour Market \& Tax Policy in the EMU", working paper $n^{\circ}$ 99-02, March.

"Programme de travail 1999", working paper n 99-01, January.

\section{8}

"Rapport d'activité 1998", working paper n98-15, December.

"Monetary Policy under a Fixed Exchange Rate Regime, The Case of France 1987-1996", B. Mojon, working paper $n^{\circ} 98-14$, December.

"Wages and Unemployment: Trade-off Under Different Labour Market Paradigms", O. Bontout and S. Jean, working paper $n^{\circ} 98-13$, November.

"Structures financières et transmission de la politique monétaire, analyses comparatives de l’Allemagne, la France, l'Italie et le Royaume-Uni", B. Mojon, working paper $n^{\circ}$ 98-12, October.

"Le marché du travail britannique vu de France", M. Fouquin, S. Jean and A. Sztulman, working paper $n^{\circ} 98-11$, October.

"Compétitivité et régime de change en Europe Centrale", M. Aglietta, C. Baulant and V. Coudert, working paper $n^{\circ} 98-10$, October. 
What Drove Relative Wages in France? Structural Decomposition Analysis in a General Equilibrium Framework, 1970-1992

"Sensibilité des salaires relatifs aux chocs exogènes de commerce international et de progrès technique : une évaluation d'équilibre général", S. Jean and O. Bontout, working paper $n^{\circ}$ 98-09, September.

"Evolution sur longue période de l'intensité énergétique", P. Villa, working paper $n^{\circ}$ 98-08, August.

"Sacrifice Ratios in Europe : a Comparison", L. Boone, B. Mojon, working paper $n^{\circ}$ 98-07, August.

"La politique monétaire et la crise japonaise", S. Guichard, working paper $n^{\circ}$ 98-06, July.

"La régionalisation du commerce international : une évaluation par les intensités relatives bilatérales", M. Freudenberg, G. Gaulier, D. Ünal-Kesenci, working paper $n^{\circ}$ 98-05, July.

"Pegging the CEEC's Currencies to the Euro", A. Bénassy-Quéré, A. Lahrèche-Révil, working paper $n^{\circ} 98-04$, July.

"The International Role of Euro", A. Bénassy-Quéré, B. Mojon, A.D. Schor, working paper $n^{\circ}$ 98-03, July.

"EMU and Transatlantic Exchange Rate Stability", A. Bénassy-Quéré and B. Mojon, working paper $n^{\circ}$ 98-02, April.

"Programme de travail 1998", J.C. Berthélemy, working paper $n^{\circ}$ 98-01, April.

\section{7}

"Why the euro will be strong: an approach based on equilibrium exchange rates", M. Aglietta, C. Baulant and V. Coudert, working paper $n^{\circ}$ 97.18, December.

"How Foreign Direct Investment Affects International Trade and Competitiveness ; an Empirical Assessment", L. Fontagné and M. Pajot, working paper $n^{\circ}$ 97-17, December.

"Cycles de poduction industrielle : une analyse historique dans le domaine des fréquences", P. Villa, working paper $n^{\circ} 97-16$, November.

"Internal and External Policy Coordination : a Dynamic Analysis", F. Capoën and P. Villa, working paper $n^{\circ} 97-15$, November.

"Optimal Pegs for Asian Currencies", A. Bénassy-Quéré, working paper $n^{\circ}$ 97-14, October. OUT-OF-PRINT

"Pour ou contre le système commun de TVA ?", C. Lefebvre, working paper $n^{\circ}$ 97-13, June. 
"The Euro and Exchange Rate Stability", A. Bénassy-Quéré, B. Mojon and J. Pisani-Ferry, working paper $n^{\circ} 97-12$, June.

"Estimation du cycle à l'aide d'un modèle à tendance stochastique and application au cas du Royaume-Uni", L. Boone, working paper $n^{\circ}$ 97-11, June.

"Looking ofr French Monetary Policy", B. Mojon, working paper $n^{\circ}$ 97-10, June. OUT-OFPRINT

"Incertitude sur le choix du modèle et rationalité", P. Villa, working paper $n^{\circ}$ 97-09, May.

"Quel est l'impact du commerce extérieur sur la productivité et l'emploi ? ", O. Cortes and S. Jean, working paper $n^{\circ}$ 97-08, April.

"Trade Patterns Inside The single Market", L. Fontagné, M. Freudenberg and N. Péridy, working paper $n^{\circ}$ 97-07, April.

"The Exchange Rate Policy of the Euro: A Matter of Size", P. Martin, working paper $n^{\circ} 97-$ 06, April. OUT-OF-PRINT

"Ces taux de de change réels qui bifurquent", P. Villa, working paper $n^{\circ}$ 97-05, April.

"Chômage non-qualifié et imitation : les raisons d'un accord international sur la propriété intellectuelle", L. Fontagné and J.L. Guérin, working paper $n^{\circ}$ 97-04, March.

"Symmetry and Assymmetry of Supply and Demand Shocks in the European Union: a Dynamic Analysis", L. Boone, working paper $n^{\circ}$ 97-03, February. OUT-OF-PRINT

"Interest Rates In East Asian Countries: Internal Financial Structures and International Linkages, I. Bensidoun, V. Coudert and L. Nayman, working paper $n^{\circ}$ 97-02, January. OUTOF-PRINT

"Intra-Industry Trade: Methodological Issues Reconsidered", L. Fontagné and M. Frendenberg, working paper $n^{\circ}$ 97-01, January. OUT-OF-PRINT

\section{6}

"The Cost of Fiscal Retrenchment Revisited: How Strong is the Evidence?", P. Cour, E. Dubois, S. Mahfouz and J. Pisani-Ferry, working paper $n^{\circ}$ 96-16, December.

"Les dynamiques sectorielles de la croissance industrielle en Europe Centrale", F. Lemoine, working paper $n^{\circ} 96-15$, December.

"Growth and Agglomeration", P. Martin and G.I.P. Ottaviano, working paper $n^{\circ}$ 96-14, December. OUT-OF-PRINT 
What Drove Relative Wages in France? Structural Decomposition Analysis in a General Equilibrium Framework, 1970-1992

"La coordination interne et externe des politiques économiques : une analyse dynamique", F. Capoen and P. Villa, working paper $n^{\circ}$ 96-13, December. OUT-OF-PRINT

"L’intégration asymétrique au sein du continent américain : un essai de modélisation", P. Cour and F. Rupprecht, working paper $n^{\circ}{ }^{\circ} 96-12$, October. 